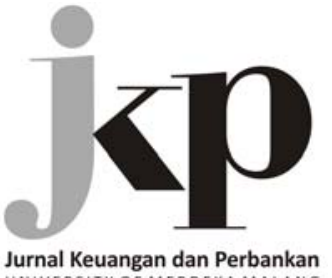

UNIVERSITY OF MERDEKA MALANG

Article history:

Received: 2019-08-27

Revised: 2019-09-06

Accepted: 2019-10-04

Keywords:

ASEAN-5, bank systemic risk; financial crisis; financial integration

JEL Classification: F36, G21, G28

Kata kunci:

ASEAN-5, risiko sistemik bank; krisis keuangan; integrasi keuangan

$\triangle$ Corresponding Author:

Herman Saheruddin:

Tel. +62 215151000

E-mail:herman.saheruddin@lps.go.id

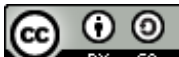

This is an open access article under the CC-BY-SA license

\section{Financial crisis and cointegration of systemic risk in Southeast Asian banking}

\author{
Herman Saheruddin ${ }^{1}$, Wahyoe Soedarmono ${ }^{2}$ \\ ${ }^{1}$ Indonesia Deposit Insurance Corporation \\ Jl. Jenderal Sudirman Kav.52-53, Jakarta, 12190, Indonesia \\ ${ }^{2}$ Department of Banking and Finance, Faculty of Business, Sampoerna University \\ Jl. Raya Pasar Minggu Kav.16, Jakarta, 12780, Indonesia
}

\section{Abstract}

This paper aims to investigate the banking sector integration through a cointegration analysis of bank systemic risk in ASEAN-5 from 1998 to 2013 by taking financial crises into consideration. Our empirical findings highlight that there is one cointegrating vector in general, suggesting that the ASEAN-5 banking sectors are not completely segmented in terms of systemic risk. A closer investigation, however, reveals that the banking sectors were completely segmented during the 1997/ 1998 Asian financial crisis (AFC) and partially segmented during the 2008 global financial crisis (GFC). The latter might indicate an improvement in banking sector integration in several countries of ASEAN-5 during the GFC compared to during the AFC. Hence, this paper highlights that the agenda of banking sector integration in ASEAN-5 should consider the influence of financial crises to ensure the effectiveness of cross-border crisis management protocol when the ASEAN-5 banking sector tends to be segmented in times of crisis. In general, portfolio diversification in ASEAN-5 also remains beneficial for global investors in banking.

\section{Abstrak}

Artikel ini bertujuan untuk menyelidiki integrasi sektor perbankan melalui analisis kointegrasi risiko sistemik bank di ASEAN-5 dari tahun 1998 hingga 2013 dengan mempertimbangkan krisis keuangan. Temuan empiris kami menyoroti bahwa ada satu vektor kointegrasi secara umum, menunjukkan bahwa sektor perbankan ASEAN-5 tidak sepenuhnya tersegmentasi dalam hal risiko sistemik. Investigasi yang lebih dekat, bagaimanapun, mengungkapkan bahwa sektor perbankan sepenuhnya tersegmentasi selama krisis keuangan Asia (AFC) 1997/1998 dan sebagian tersegmentasi selama krisis keuangan global (GFC) 2008. Yang terakhir mungkin menunjukkan peningkatan integrasi sektor perbankan di beberapa negara ASEAN-5 selama GFC dibandingkan dengan selama AFC. Oleh karena itu, makalah ini menyoroti bahwa agenda integrasi sektor perbankan di ASEAN-5 harus mempertimbangkan pengaruh krisis keuangan untuk memastikan efektivitas protokol manajemen krisis lintas batas ketika sektor perbankan ASEAN-5 cenderung tersegmentasi pada saat krisis. Secara umum, diversifikasi portofolio di ASEAN-5 juga tetap bermanfaat bagi investor global di bidang perbankan.

Disclaimer: All views in this paper are the authors and do not necessarily reflect the views of Indonesia Deposit Insurance Corporation.

How to Cite: Saheruddin, H., \& Soedarmono, W. (2019). Financial crisis and cointegration of systemic risk in Southeast Asian banking. Jurnal Keuangan dan Perbankan, 23(4), 479-488. https://doi.org/10.26905/jkdp.v23i4.3669 


\section{Jurnal Keuangan dan Perbankan}

Volume 23, Issue 4, October 2019: 479-488

\section{Introduction}

The simple definition of financial integration is when financial markets in an economy become more closely interrelated with other economies (Brouwer, 2005). This integration brings three benefits for the economies, including more risk-sharing opportunities, better capital allocation, and improved financial development for higher economic growth (Baele et al., 2004). However, there is also a potential downside of financial integration, in which financial shock from one country can have a contagion impact on neighboring economies (Beine et al., 2010).

This paper revisits prior literature on the feasibility of the ASEAN financial integration, especially related to the ASEAN banking sector integration. Though there has been a vast literature on financial integration, surprisingly studies on banking sector integration in ASEAN are still relatively sparse. Financial integration initiatives in these countries have been so far focusing on the capital market, such as the Chiang Mai Initiative launched in May 2000 and the Asian Bond Market Initiative in August 2003 for ASEAN+3 countries. Meanwhile, the financial sectors in these countries are still dominated by commercial banking (Felman et al., 2014; Soedarmono \& Tarazi, 2013; Yamanaka, 2013).

Filling this gap in the literature, our paper focuses to study banking sector integration in ASEAN countries. More specifically, we focus on a sample of ASEAN-5 countries (Indonesia, Malaysia, Thailand, the Philippines, and Singapore) as these five countries exhibit higher aggregate output than other ASEAN countries. By 2012, Indonesia's gross domestic product (GDP) reaches USD 878,043 million, while Thailand, Malaysia, Singapore, and the Philippines reaches the level GDP of USD 400,916 million, USD 312,413 million, USD 287,374 million, and USD 272,207 million, respectively. Meanwhile, GDP in ASEAN members other than ASEAN5 is as follows: Vietnam (USD 170,020 million), Brunei Darussalam (USD 16,954 million), Cambodia (USD
14,038 million), Myanmar (USD 59,444 million), and Laos (USD 9,171 million). Hence, ASEAN-5 economic dynamics can affect the Southeast Asian economy as a whole. Different from most previous studies on financial integration that looked at crossborder asset holdings and liabilities, we consider banking sector integration using the interdependence of systemic risk in banking among these countries. Assessing the interdependence of systemic risk in the banking sector is essential to provide a benchmark for policymakers to encourage financial integration and stability. Specifically, understanding the extent to which contagion risk in banking across countries converges to unity will enable us to assess whether the banking crisis can spread from one country to another in the same region.

Furthermore, we assess whether the banking sector integration changes during the two last most severe crisis periods, i.e. during the Asian financial crisis (AFC) and the global financial crisis (GFC). These crises alter intraregional equity investments in the Asia-Pacific region (Kim et al., 2015). Yet, Lucey et al. (2018) also suggest that research on financial integration should also take into account the impact of the financial crisis, especially the GFC because of cross-border interbank lending declines following the GFC. To isolate the impact of the two crises in this study, we limit our sample period from 1998 through 2013 before the US Federal Open Market Committee (FOMC) started to taper its QE3 starting in January 2014 (Park, 2013).

By way of preview, our empirical findings using weekly data from January 1998 to December 2013 are generally supportive of the notion that the ASEAN-5 banking sector is not completely segmented and hence, policy initiatives to strengthen banking sector integration in ASEAN-5 can be encouraged. A closer investigation, however, reveals that no cointegrating vector can be detected during the AFC and only several cointegrating vectors during the GFC. In this regard, the ASEAN-5 banking sectors were completely segmented during the AFC 


\section{Financial crisis and cointegration of systemic risk in Southeast Asian banking}

Herman Saheruddin, Wahyoe Soedarmono

and partially segmented during the GFC, especially between Indonesia and Malaysia, Malaysia and Singapore, and Malaysia and Thailand. The latter might indicate an improvement in banking sector integration in several countries of ASEAN-5 during the GFC compared to during the AFC.

The rest of this paper is structured as follows. Section 2 presents our hypotheses development. Section 3 presents the method, data, and analysis. Section 4 describes our empirical results. Section 5 presents discussion. Section 6 describes the conclusion, limitations, and suggestions for further research.

\section{Hypotheses Development}

Prior literature considers at least two macroeconomic indicators to depict financial integration. The first indicator is related to exchange rates comovement among countries in which several currencies are treated as the same assets. Higher exchange rates comovement means higher feasibility of financial integration (Dwyer \& Wallace, 1992; Baig \& Goldfajn, 1999; Forbes \& Rigobon, 2002). The second indicator is associated with stock market comovement (Corhay et al., 1993; Click \& Plummer, 2005; Kim et al., 2015).

Meanwhile, the notion of financial integration can also be linked to "contagion" or "cointegration". Contagion is commonly used to define a condition in which short-run correlations across countries increases after the occurrence of initial shocks (Baig \& Goldfajn, 1999; Forbes \& Rigobon, 2002; Khan \& Park, 2009), while cointegration is the occurrence of long-run equilibrium in which long-run correlations between indicators across countries outweigh shortrun correlations (Click \& Plummer, 2005). Indeed, cointegration might not always be associated with integration or interdependence, if there is heteroscedasticity (Dimpfl, 2014). However, cointegration in stock market indicators across countries can be due to common endowments and degree of technological progress in these countries, even if the countries have no trade linkages (Lence \& Falk, 2005). Hence, it is not a coincidence that countries with cointegrated stock markets are likely to have identical economic fundamentals that will enable economic and financial sector environments to be harmonized. Arguably, economic and financial integration among such countries is feasible.

In the ASEAN context, trade linkages have emerged and several initiatives - such as Chiang Mai Initiatives and Asian Bond Markets Initiative have also been in place (Institute of International Monetary Affairs, 2006; Yu et al., 2010). Phrased differently, assessing the feasibility of financial integration using a cointegration analysis is relevant in the ASEAN context because ASEAN countries are likely to have similar fundamentals due to trade linkages and financial integration initiatives that were undertaken so far. In the context of banking sector integration, we are going to test whether systemic risks between commercial banks in each pair of countries in ASEAN-5 are cointegrated. Hence, our first hypothesis to test in this paper:

$H_{1}$ : there is a banking sector cointegration among ASEAN-5 countries

Furthermore, we are going to test whether the banking sector integration changes during the two last most severe crisis periods, the AFC and the GFC. Accordingly, our second hypothesis to test in this paper:

$\mathrm{H}_{2}$ : the banking sector cointegration among ASEAN-5 countries changes during the AFC and the GFC.

\section{Method, Data, and Analysis}

We initially retrieve weekly market index for each country from the last January 1998 to December 2013. We stop the sample period in December 2013 to isolate the impact of the AFC and the GFC, avoiding the potential confounding effect of the US Federal Open Market Committee (FOMC) QE3 ta- 
pering, which starts in January 2014. Moreover, we also retrieve weekly stock prices for 59 publicly listed banks in ASEAN-5 countries. We consider 59 publicly-listed banks from Indonesia (31), Malaysia (3), Philippines (12), Singapore (3) and Thailand (10). The parentheses constitute the number of banks for each country. All these data come from Thomson-Reuters DataStream International. Our sample may comprise failed and delisted banks because such banks might still affect the systemic risk of the banking system before they have failed.

Meanwhile, we compute the measure of bank systemic risk at the country level in two steps. In the first step, we compute the degree of systemic risk at the bank level. In the second step, we aggregate bank-level systemic risk to obtain the average systemic risk of the banking system as a whole.

With regards to the first step, we construct a single-index market model following Soedarmono et al. (2017) and Bautista et al. (2009) as follows:

$$
R_{i, t}=\beta R_{m, t}+\varepsilon_{i, t}
$$

$R_{i, t}$ is weekly bank $i$ 's stock returns, while $R_{m, t}$ is weekly market $m^{\prime}$ 's returns. Bank stock returns and market returns are computed as follows:

$$
R_{i, t}=\log \left(\frac{p_{t}}{p_{t-1}}\right) R_{m, t}=\log \left(\frac{\operatorname{comp}_{t}}{\operatorname{comp}_{t-1}}\right)
$$

In Eq. (2), $p$ and comp represent weekly bank stock prices and weekly stock market composite indices, respectively. Moreover, Eq. (1) is estimated using the OLS (Ordinary Least Squares) regressions from $t-51$ up to $t$. In the next turn, we retrieve the residuals of Eq. (1), so as to represent weekly banks' idiosyncratic risk. We subsequently compute an exponentially weighted moving average correlation between the idiosyncratic risk of bank $i\left(\varepsilon_{i, t}\right)$ and that of bank $j\left(\varepsilon_{j, t}\right)$ within each country that varies from week to week. These time-varying correlations are computed from $t-51$ up to $t$ based on the following formula:

$$
\rho_{i j, t}=\frac{\sum_{s=0}^{k} \lambda^{s} \varepsilon_{i, t-s} \varepsilon_{j, t-s}}{\left[\left(\sum_{s=0}^{k} \lambda^{s} \varepsilon_{i, t-s}^{2}\right)\left(\sum_{s=0}^{k} \lambda^{s} \varepsilon_{j, t-s}^{2}\right)\right]^{\frac{1}{2}}}
$$

As documented by Engle (2002), RiskMetrics uses the exponential smoother as in Eq. (3) with declining weights based on a parameter $\lambda$. We follow RiskMetrics and Engle (2002) to set $\lambda=0.94$. For each bank $i, \rho$ is the weekly average of correlation between bank $i$ 's idiosyncratic risk with other banks j's idiosyncratic risk within each country. In this regards, is the measure of bank-level systemic risk.

In the second stage, in order to obtain the measure of systemic risk in the banking system, we calculate the average value of bank-level systemic risk within each country. The average systemic risk of the banking system is denoted by INDO for Indonesia, MYS for Malaysia, PHIL for the Philippines, SING for Singapore, and THAI for Thailand.

Regarding our empirical methodology, we conduct the analysis in three steps. In the first step, we compute the degree of systemic risk in the banking system for each country described earlier. The second step examines whether the ASEAN-5 banking sector is cointegrated in terms of systemic risk from 1998 through 2013. In the third step, we repeat the second step, but we focus on observing two distinct periods: (i) the AFC period (from 1998 to 2001) and (ii) the GFC period (from 2007 to 2009).

From the second and third steps, we use a cointegration analysis in order to assess the occurrence of long-run relationships of the systemic risk of the banking system in ASEAN-5. We follow prior literature that uses the identical technique to assess 


\section{Financial crisis and cointegration of systemic risk in Southeast Asian banking}

Herman Saheruddin, Wahyoe Soedarmono

financial integration (Kasa, 1992; Corhay et al., 1993; Chung \& Liu, 1994; Richards, 1995; Click \& Plummer, 2005). Specifically, a cointegration technique comprises three stages described as follows.

In the first stage, we check whether or not the series INDO, MYS, PHIL, SING, and THAI are stationary using both the Augmented Dicky-Fuller (ADF) and Phillips-Perron (PP) unit root tests. If at least one of the five series is not stationary due to the existence of a unit root, it is sufficient to consider that a cointegration analysis is appropriate to assess long-run correlations between the five series.

In the second stage, we determine the optimal lag length or the number of lags in the Vector Auto Regression (VAR) model before building a cointegrating relationship (Richards, 1995; Click \& Plummer, 2005). We use several tests to identify the number of optimal lags in the VAR model, such as (i) Likelihood Ratio (LR) test; (iii) the FPE (final prediction error) test; (iii) the Akaike Information Criterion (AIC); (iv) the Schwarz information criterion (SIC); and (v) the Hannah-Quinn information criterion (HIC). The number of optimal lags is detected when most of these tests are accepted.In the third stage, we run cointegration tests by identifying deterministic trend assumption. We use three tests, such as the Log Likelihood test, the AIC test, and the SIC test. The specification of deterministic trend assumption is chosen, if most of these tests are significant. As in Click \& Plummer (2005) who analyze the correlations of stock market in ASEAN-5, if $n$ variables have $p$ cointegrating vectors, these $n$ variables have $n-p$ common trends. If $n-p=1$, it suggests that no potential benefits of portfolio diversification in the long run, because the correlation of systemic risk in the banking system converges to unity. In other words, ASEAN-5 banking sector is fully integrated in this regard. When $n-p=5$, it suggests that the banking sector systemic risk across ASEAN-5 countries are perfectly segmented, because there is no cointegrating vector $(p=0)$.

\section{Results}

In this paper, the framework of presenting our empirical results follows that of Soedarmono et al. (2018) who assess the feasibility of stock market integration using a cointegration analysis of liquidity risk. As the first step, Table 1 presents the ADF and PP unit root tests for the series INDO, MYS, PHIL, SING, and THAI. Although the series INDO, MYS, PHIL and SING are stationary, we find that THAI has a unit root, because the ADF and PP unit root tests are not rejected. This suggests that cointegration technique is appropriate, because one of the five series is not stationary.

Table 1. Unit root tests

\begin{tabular}{lcc}
\hline \multicolumn{1}{c}{ Series } & $\begin{array}{c}\text { Augmented } \\
\text { Dicky-Fuller test }\end{array}$ & $\begin{array}{c}\text { Phillips- } \\
\text { Perron test }\end{array}$ \\
\hline INDO & $-3.713^{* * *}$ & $-3.725^{* * *}$ \\
MYS & $-3.774^{* * *}$ & $-3.917^{* * *}$ \\
PHIL & $-1.954^{* *}$ & $-1.989^{* *}$ \\
SING & $-4.291^{* * *}$ & $-4.225^{* * *}$ \\
THAI & -1.475 & -1.329 \\
\hline
\end{tabular}

$* * *, * *, *$ indicate significance at the $1 \%, 5 \%$ and $10 \%$ levels, respectively.

In Table 2, we document that there is one cointegrating vector from a cointegration analysis in ASEAN-5 during the 1998-2013 period. This indicates that the ASEAN-5 banking sector is not fully segmented and hence, the ASEAN-5 banking sector integration is feasible. Moreover, bilateral cointegration tests also reveal that the pairs of countries have one cointegrating vector, indicating the existence of long-run relationship in the systemic risk of banking system. Eventually, Table 3 and Table 4 report the results of a cointegration analysis when we consider the AFC and the GFC periods, respectively. 
In Table 3 and Table 4, we perform bilateral cointegration tests. As shown in Table 3, the empirical results during the AFC show that no cointegrating vector can be detected. Similarly, the majority of the pairs of countries have no cointegrating vector during the GFC as shown in Table 4. Only Indonesia-Malaysia, MalaysiaSingapore, and Malaysia and Thailand that are cointegrated during the GFC, suggesting a potential improvement in banking sector integration in these countries during the GFC compared to during the AFC.

\section{Discussion}

Our main results indicate that the ASEAN-5 banking sector is not fully segmented and hence, the ASEAN-5 banking sector integration is feasible. Moreover, bilateral cointegration tests also reveal that the pairs of countries have one cointegrating vector, indicating the existence of long-run relationship in the systemic risk of banking systems in ASEAN-5 countries.

Our cointegration results in ASEAN-5 during financial crises are somehow consistent with the findings of previous studies highlighting that cross-bor-

Table 2. Cointegration tests over the 1998-2013 period.

\begin{tabular}{|c|c|c|c|c|c|c|c|c|}
\hline \multirow[t]{2}{*}{ Model } & \multirow{2}{*}{$\begin{array}{c}\text { Optimum } \\
\text { Lag } \\
\text { Length }\end{array}$} & \multicolumn{3}{|c|}{$\begin{array}{c}\text { Deterministic Trend } \\
\text { Assumption }\end{array}$} & \multirow{2}{*}{$\begin{array}{l}\text { Null } \\
\text { Hypothesis }\end{array}$} & \multirow{2}{*}{$\begin{array}{l}\text { Trace } \\
\text { Statistic }\end{array}$} & \multirow{2}{*}{$\begin{array}{c}\text { Max-Eigen } \\
\text { Statistic }\end{array}$} & \multirow{2}{*}{$\begin{array}{l}\text { Cointegrating } \\
\text { Vector }\end{array}$} \\
\hline & & Data trend & Intercept & Trend & & & & \\
\hline $\begin{array}{l}\text { Multilateral } \\
\text { co-integration test } \\
\text { ASEAN-5 }\end{array}$ & 1 & No & No & No & $\begin{array}{r}r=0 \\
r \leq 1\end{array}$ & $\begin{array}{l}92.4996^{* * *} \\
51.7900^{* * *}\end{array}$ & $\begin{array}{r}40.7095^{* * *} \\
20.3959\end{array}$ & 1 \\
\hline $\begin{array}{l}\text { Bilateral } \\
\text { co-integration test }\end{array}$ & & & & & & & & \\
\hline$I N D O-M Y S$ & 1 & No & No & No & $\begin{array}{r}r=0 \\
r \leq 1\end{array}$ & $\begin{array}{l}27.1209^{* * *} \\
11.9653^{* * *}\end{array}$ & $\begin{array}{l}15.1556^{* * *} \\
11.9653^{* * *}\end{array}$ & 1 \\
\hline INDO - PHIL & 1 & No & No & No & $\begin{array}{r}\mathrm{r}=0 \\
\mathrm{r} \leq 1\end{array}$ & $\begin{array}{r}20.4123^{* * *} \\
3.7928^{* * *}\end{array}$ & $\begin{array}{r}16.6195^{* * *} \\
3.7928^{* * *}\end{array}$ & 1 \\
\hline INDO - SING & 1 & No & No & No & $\begin{array}{r}r=0 \\
r \leq 1\end{array}$ & $\begin{array}{l}36.2225^{* * *} \\
11.2035^{* * *}\end{array}$ & $\begin{array}{l}25.0189^{* * *} \\
11.2035^{* * *}\end{array}$ & 1 \\
\hline INDO - THAI & 1 & No & No & No & $\begin{array}{r}\mathrm{r}=0 \\
\mathrm{r} \leq 1\end{array}$ & $\begin{array}{r}23.3962^{* * *} \\
2.5452\end{array}$ & $\begin{array}{r}20.8510^{* * *} \\
2.545204\end{array}$ & 1 \\
\hline MYS - PHIL & 1 & No & Yes & No & $\begin{array}{r}r=0 \\
r \leq 1\end{array}$ & $\begin{array}{l}27.5202^{* * *} \\
12.9847^{* * *}\end{array}$ & $\begin{array}{l}14.5355^{* * *} \\
12.9847^{* * *}\end{array}$ & 1 \\
\hline MYS - SING & 2 & No & No & No & $\begin{array}{r}r=0 \\
r \leq 1\end{array}$ & $\begin{array}{l}35.7495^{\star * *} \\
13.6492^{* * *}\end{array}$ & $\begin{array}{l}22.1003^{* * *} \\
13.6492^{* * *}\end{array}$ & 1 \\
\hline MYS - THAI & 1 & No & No & No & $\begin{array}{r}\mathrm{r}=0 \\
\mathrm{r} \leq 1\end{array}$ & $\begin{array}{r}16.7325^{* * *} \\
2.1715\end{array}$ & $\begin{array}{r}14.5609^{* * *} \\
2.1715\end{array}$ & 1 \\
\hline PHIL - SING & 1 & No & No & No & $\begin{array}{r}\mathrm{r}=0 \\
\mathrm{r} \leq 1\end{array}$ & $\begin{array}{r}28.5473^{* *} \\
4.0415\end{array}$ & $\begin{array}{r}24.5058^{* * *} \\
4.0415\end{array}$ & 1 \\
\hline PHIL - THAI & 1 & No & No & No & $\begin{array}{r}r=0 \\
r \leq 1\end{array}$ & $\begin{array}{r}15.1086^{* *} \\
1.5934\end{array}$ & $\begin{array}{r}13.5152^{* *} \\
1.5934\end{array}$ & 1 \\
\hline SING - THAI & 1 & No & No & No & $\begin{array}{r}\mathrm{r}=0 \\
\mathrm{r} \leq 1 \\
\end{array}$ & $\begin{array}{r}23.1864^{* * *} \\
2.1519 \\
\end{array}$ & $\begin{array}{r}21.0345^{* * *} \\
2.1519 \\
\end{array}$ & 1 \\
\hline
\end{tabular}

Notes: Cointegration tests are conducted using weekly data from January, 1998 to December, 2013. We use Johansen (1988) to test for multivariate (multilateral) and bivariate (bilateral) cointegrating relationships amongst the five series. ASEAN-5 consists of Indonesia (INDO), Malaysia (MYS), The Philippines (PHIL), Singapore (SING) and Thailand (THAI). Optimum lag lengths indicate the optimal number of lags in the VAR model. $r$ indicates the number of cointegrating vectors. $* * *, * *, *$ indicate significance at the $1 \%, 5 \%$ and $10 \%$ levels, respectively. 


\section{Financial crisis and cointegration of systemic risk in Southeast Asian banking}

Herman Saheruddin, Wahyoe Soedarmono

der interbank lending declines in times of crisis, especially during the GFC. As in Lucey et al. (2018), cross-border interbank lending around the world generally declines from USD 12 trillion in mid-2008 to USD 7 trillion after the GFC up to 2013 as described in Lucey et al. (2018).

Regarding ASEAN-5 specifically, intraregional cross-border banking activities during the GFC might be outweighed by European banks' lending expansion to Asia Pacific (Remolona and Shim, 2015). Accordingly, the ASEAN-5 banking sector tends to be segmented during the GFC period. Likewise, the extent to which the ASEAN-5 banking sector is segmented during the AFC period can partly be driven by the risk aversion of ASEAN banks to engage in intraregional cross-border activities and a decline in investor confidence in ASEAN banks. For instance, US, and European banks shifted their lending from Asia to Latin America during the AFC as described by Gochoco-Bautista \& Remolona (2017).

Table 3. Cointegration tests during the AFC (1998-2001)

\begin{tabular}{|c|c|c|c|c|c|c|c|c|}
\hline \multirow{2}{*}{ Model } & \multirow{2}{*}{$\begin{array}{l}\text { Optimum } \\
\text { Lag } \\
\text { Length }\end{array}$} & \multicolumn{3}{|c|}{ Deterministic Trend Assumption } & \multirow{2}{*}{$\begin{array}{c}\text { Null } \\
\text { Hypothesis }\end{array}$} & \multirow{2}{*}{$\begin{array}{l}\text { Trace } \\
\text { Statistic }\end{array}$} & \multirow{2}{*}{$\begin{array}{l}\text { Max-Eigen } \\
\text { Statistic }\end{array}$} & \multirow{2}{*}{$\begin{array}{c}\text { Cointegrating } \\
\text { Vector }\end{array}$} \\
\hline & & Data Trend & Intercept & Trend & & & & \\
\hline $\begin{array}{l}\text { Multilateral } \\
\text { co-integration test } \\
\text { ASEAN-5 }\end{array}$ & 1 & No & No & No & $\begin{array}{r}r=0 \\
r \leq 1\end{array}$ & $\begin{array}{l}35.0762 \\
20.4683\end{array}$ & $\begin{array}{l}14.6078 \\
10.5003\end{array}$ & 0 \\
\hline $\begin{array}{l}\text { Bilateral } \\
\text { co-integration test }\end{array}$ & & & & & & & & \\
\hline$I N D O-M Y S$ & 1 & No & No & No & $\begin{array}{r}r=0 \\
r \leq 1\end{array}$ & $\begin{array}{l}4.6295 \\
1.0041\end{array}$ & $\begin{array}{l}3.6254 \\
1.0041\end{array}$ & 0 \\
\hline INDO - PHIL & 1 & No & No & No & $\begin{array}{r}\mathrm{r}=0 \\
\mathrm{r} \leq 1\end{array}$ & $\begin{array}{l}5.4335 \\
1.6782\end{array}$ & $\begin{array}{l}3.7552 \\
1.6782\end{array}$ & 0 \\
\hline INDO - SING & 1 & No & No & No & $\begin{array}{r}r=0 \\
r \leq 1\end{array}$ & $\begin{array}{l}9.6639 \\
2.8960\end{array}$ & $\begin{array}{l}6.7679 \\
2.8960\end{array}$ & 0 \\
\hline INDO - THAI & 1 & No & No & No & $\begin{array}{r}\mathrm{r}=0 \\
\mathrm{r} \leq 1\end{array}$ & $\begin{array}{l}9.6639 \\
2.8960\end{array}$ & $\begin{array}{l}6.7679 \\
2.8960\end{array}$ & 0 \\
\hline MYS - PHIL & 3 & No & Yes & No & $\begin{array}{r}r=0 \\
r \leq 1\end{array}$ & $\begin{array}{r}11.8878 \\
1.3228\end{array}$ & $\begin{array}{r}10.5650 \\
1.3228\end{array}$ & 0 \\
\hline MYS - SING & 1 & No & No & No & $\begin{array}{r}r=0 \\
r \leq 1\end{array}$ & $\begin{array}{l}4.2638 \\
0.8755\end{array}$ & $\begin{array}{l}3.3882 \\
0.8755\end{array}$ & 0 \\
\hline MYS - THAI & 1 & No & No & No & $\begin{array}{r}\mathrm{r}=0 \\
\mathrm{r} \leq 1\end{array}$ & $\begin{array}{l}2.3201 \\
0.5396\end{array}$ & $\begin{array}{l}1.7805 \\
0.5396\end{array}$ & 0 \\
\hline PHIL - SING & 1 & No & Yes & No & $\begin{array}{r}r=0 \\
r \leq 1\end{array}$ & $\begin{array}{r}13.1468 \\
2.5499\end{array}$ & $\begin{array}{r}10.5968 \\
2.5499\end{array}$ & 0 \\
\hline PHIL - THAI & 1 & No & No & No & $\begin{array}{r}r=0 \\
r \leq 1\end{array}$ & $\begin{array}{l}3.2083 \\
0.1776\end{array}$ & $\begin{array}{l}3.0308 \\
0.1776\end{array}$ & 0 \\
\hline SING - THAI & 1 & No & No & No & $\begin{array}{r}r=0 \\
r \leq 1\end{array}$ & $\begin{array}{l}6.4229 \\
0.1099 \\
\end{array}$ & $\begin{array}{l}6.3131 \\
0.1099 \\
\end{array}$ & 0 \\
\hline
\end{tabular}

Notes: Cointegration tests are conducted using weekly data from January, 1998 to December, 2001. We use Johansen (1988) to test for multivariate (multilateral) and bivariate (bilateral) cointegrating relationships amongst the five series. ASEAN-5 consists of Indonesia (INDO), Malaysia (MYS), The Philippines (PHIL), Singapore (SING) and Thailand (THAI). Optimum lag lengths indicate the optimal number of lags in the VAR model. $r$ indicates the number of cointegrating vectors. $* * *, * * *$ indicate significance at the $1 \%, 5 \%$ and $10 \%$ levels, respectively. 


\section{Conclusion, Limitations, and Suggestions Conclusion}

This paper attempts to examine the feasibility of the ASEAN-5 banking sector integration. Our original contribution is that we assess the integration using a cointegration analysis of the systemic risk in the banking system across ASEAN-5 countries. Our empirical results suggest that although there is one cointegrating vector from 1998 to 2013, indicating that banking sector integration in ASEAN-5 does exist, we find that no cointegrating vector can be detected during the AFC and limited numbers of cointegrating vectors during the GFC.
Hence, the likelihood of banking sector integration in ASEAN-5 declines in times of crisis.

Our findings provide at least two policy implications. First, policy initiatives to strengthen banking sector integration in ASEAN-5 can be encouraged, but the influence of financial crisis should also be anticipated through improved cross-border crisis management. This is to ensure the efforts to deal with banking crisis and contagion risk can be effectively transmitted to ASEAN-5 countries when the banking sector is segmented. Second, our results also suggest that diversifying portfolio investment within ASEAN-5 is still beneficial for global inves-

Table 4. Cointegration tests during the GFC (2007-2009)

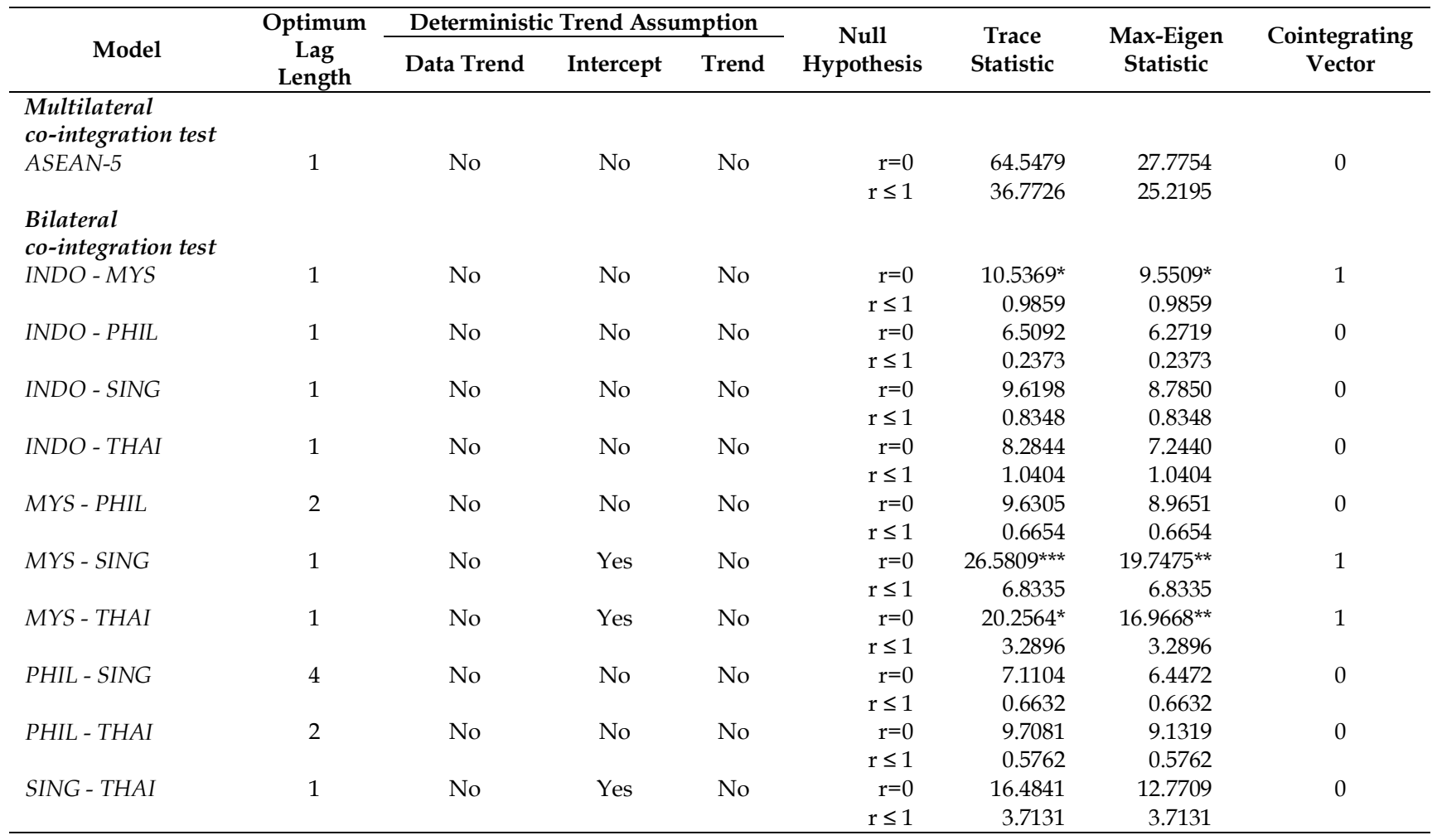

Notes: Cointegration tests are conducted using weekly data from January, 2007 to December, 2009. We use Johansen (1988) to test for multivariate (multilateral) and bivariate (bilateral) cointegrating relationships amongst the five series. ASEAN-5 consists of Indonesia (INDO), Malaysia (MYS), The Philippines (PHIL), Singapore (SING) and Thailand (THAI). Optimum lag lengths indicate the optimal number of lags in the VAR model. $r$ indicates the number of cointegrating vectors. ${ }^{* * *}, * *, *$ indicate significance at the $1 \%, 5 \%$, and $10 \%$ levels, respectively. 


\section{Financial crisis and cointegration of systemic risk in Southeast Asian banking}

Herman Saheruddin, Wahyoe Soedarmono

tors in banking, given the fact that the ASEAN-5 banking sector is not fully integrated.

\section{Limitations and suggestions}

In testing our research hypotheses, there are two limitations in our methodology. First, we rely on systemic risk measures that can be applied only for publicly listed commercial banks in ASEAN-5 countries. Therefore, we assume that only publicly listed banks that can contribute to systemic risk in the banking sector. Though this assumption might be justifiable, we should check how privately-held banks in these countries might contribute to sys- temic risk in the banking sector. Second, aside for financial crises period of AFC and GFC, there are turbulence periods such as the QE3 tapering period and trade war period that have not triggered a financial crisis in these countries, but we might want to look at how the banking sector cointegration changes during these volatile periods. Accordingly, we leave these areas for further research.

\section{Acknowledgement}

We thank the managing editor and two anonymous referees for their comments to improve this paper.

\section{References}

Baele, L., Ferrando, A., Hördahl, P., Krylova, E., \& Monnet, C. (2004). Measuring financial integration in the Euro Area. European Central Bank Occasional Paper Series, 14.

Baig, T., \& Goldfajn, I. (1999). Financial contagion in the Asian crisis. IMF Staff Papers, 46(2), 167-195. https://doi.org/10.2307/3867666

Bautista, C., Rous, P., \& Tarazi, A. (2008). The determinants of domestic and cross border bank contagion risk in Southeast Asia. Revue économique, 59(6), 1215-1242. https://doi.org/10.3917/reco.596.1215

Beine, M., Cosma, A., \& Vermeulen, R. (2010). The dark side of global integration: Increasing tail dependence. Journal of Banking and Finance, 34(1), 184-192. https://doi.org/10.2139/ssrn.1253362

Brouwer, G. (2005). Monetary and financial integration in Asia: Empirical evidence and issues. Asia Economic Cooperation and Integration. Manila: Asia Development Bank.

Chung, P., \& Liu, D. (2004). Common stochastic trends in Pacific Rim stock markets. Quarterly Review of Economics and Finance, 34, 241-259. https://doi.org/10.1016/1062-9769(94)90026-4

Click, R. W., \& Plummer, M. G. (2005). Stock market integration in ASEAN after the Asian financial crisis. Journal of Asian Economics, 16(1), 5-28. https://doi.org/10.1016/j.asieco.2004.11.018

Corhay, A., Rad, A. T., \& Urbain, J. P. (1993). Common stochastic trends in European stock markets. Economics Letters, 42, 385-390. https://doi.org/10.1016/0165-1765(93)90090-Y

Dimpfl, T. (2014). A note on cointegration of international stock market indices. International Review of Financial Analysis, 33, 10-16. https://doi.org/10.1016/j.irfa.2013.07.005

Dwyer Jr, G. P., \& Wallace, M. S. (1992). Cointegration and market efficiency. Journal of International Money and Finance, 11, 318-327. https://doi.org/10.1016/0261-5606(92)90027-U

Engle, R. (2002). Dynamic conditional correlation: a simple class of multivariate GARCH. Journal of Business and Economic Statistics, 17(5), 425-446. 


\section{Jurnal Keuangan dan Perbankan}

Volume 23, Issue 4, October 2019: 479-488

Felman, J., Gray, S., Goswami, M., Jobst, A. A., Pradhan, M., Peiris, S., \& Seneviratne, D. (2014). ASEAN5 bond market development: Where does it stand? Where is it going. Asian-Pacific Economic Literature, 28(1), 60-75. https://doi.org/10.1111/apel.12051

Forbes, K. J., \& Rigobon, R. (2002). No contagion, only interdependence: measuring stock market comovements. The journal of Finance, 57(5), 2223-2261. https://doi.org/10.1111/0022-1082.00494

Gochoco-Bautista, M. S., \& Remolona, E. M. (2017). The promises of bank integration in ASEAN: Is There a Catch?. The ASEAN Economic Community Into 2025 and Beyond Vol. 5.

Institute for International Monetary Affairs. (2006). Intra-regional exchange rate stability and prevention of financial crisis in East Asia. Working Group Report of the Network of East Asian Think-tanks (NEAT).

Kasa, K. (1992). Common stochastic trends in international stock markets. Journal of Monetary Economics, 29, 95-124. https://doi.org/10.1016/0304-3932(92)90025-W

Khan, S., \& Park, K. W. K. (2009). Contagion in the stock markets: The Asian financial crisis revisited. Journal of Asian Economics, 20(5), 561-569. https://doi.org/10.1016/j.asieco.2009.07.001

Lence, S., \& Falk, B. (2005). Cointegration, market integration, and market efficiency. Journal of International Money and Finance, 24(6), 873-890. https://doi.org/10.1016/j.jimonfin.2005.05.002

Lucey, B., Vigne, S. A., Ballester, L., Barbopoulos, L., Brzeszczynski, J., Carchano, O., Dimic, N., Fernandez, V., Gogolin, F., Gonzalez-Urteaga, A., Godwell, J.W., Helbing, P., Ichev, R., Keaney, F., Laing, E., Larkin, C.J., Lindbald, A., Loncarski, I., Ly K.C., Marinc, M., McGee R. J., McGroarty, F., Neville, C., O’Hagan-Luff, M., Piljak, V., Sevic, A., Sheng, X., Stafylas, D., Urquhart, A., Versteeg, R., Vu A.,N., Wolfe, S., Yarovaya, L., \& Zaghini A. (2018). Future directions in international financial integration research - A crowdsourced perspective. International Review of Financial Analysis, 56, 35-49. https://doi.org/10.1016/j.irfa.2017.10.008

Park, J. Y. (2013). Fed to taper bond buying by $\$ 10$ billion a month. Retrieved from: https://www.cnbc.com/2013/12/18/fed-begins-taper-program.html

Remolona, E. M., \& Shim, I. (2015). The rise of regional banking in Asia and the Pacific. BIS Quarterly Review, 13, September, 119-34.

Richards, A. J. (1995). Comovements in national stock market returns: Evidence of predictability, but not cointegration. Journal of Monetary Economics, 36(3), 631-654. https://doi.org/10.1016/0304-3932(95)01225-7

Soedarmono, W. (2018). Stock market integration in the Asia-Pacific Region: Evidence from cointegration of liquidity risk. Economics Bulletin, 38(1), 60-70.

Soedarmono, W., Sitorus, D., \& Tarazi, A. (2017). Abnormal loan growth, credit information sharing and systemic risk in Asian banks. Research in International Business and Finance, 42, 1208-1218. https://doi.org/10.1016/j.ribaf.2017.07.058

Soedarmono, W., \& Tarazi, A. (2013). Bank opacity, intermediation cost, and globalization: Evidence from a sample of publicly traded banks in Asia. Journal of Asian Economics, 29, 91-100. https://doi.org/10.1016/j.asieco.2013.09.003

Yamanaka, T. (2013). Integration of the ASEAN banking sector. Institute for International Monetary Affairs Newsletter, 1, 1-21.

Yu, I. W., Fung, K. P., \& Tam, C. S. (2010). Assessing financial market integration in Asia-equity markets. Journal of Banking \& Finance, 344, 2874-2885. https://doi.org/10.1016/j.jbankfin.2010.02.010. 